\title{
Substitusi terigu dengan tepung jagung dan tapioka dalam pembuatan mie instan protein tinggi: kajian dari penambahan soy protein isolate (SPI) dan Na-alginat
}

\author{
Substitution of wheat flour with corn flour and tapioca in the manufacture of high \\ protein instant noodles: a study of the addition of Soy protein isolate (SPI) and Na- \\ alginate
}

\author{
Sukamto $^{\left.1^{*}\right)}$, Jemi Arrohman ${ }^{1)}$, Sudiyono ${ }^{1)}$ \\ ${ }^{1}$ Program Studi Teknologi Hasil Pertanian, Universitas Widyagama Malang, Jawa Timur 65142 \\ "Email: sukamuwg@yahoo.com
}

Informasi Artikel:

Dikirim: 16/07/2020; ditinjau: 16/07/2020; disetujui: 11/08/2020

\begin{abstract}
The use of vegetable protein has been developed to increase the protein content of instant noodles. Indonesia is one of the countries that consumes noodles in the second place after China. These conditions led to an increase in wheat imports. In an effort to increase the protein content in instant noodles and also reduce the need for wheat, alternative local raw materials are needed to substitute wheat flour. The aim of the study was to utilize tapioca and corn flour as a substitute for wheat flour in the manufacture of instant noodles, which added soybean protein isolate (SPI) and Naalginate to increase protein content and physical properties. Factorial randomized block design (RBD) was used in this research, factor I was SPI and factor II Naalginate. The treatment was repeated 3 times. The observational variations were analyzed for variance and continued with the tukey test with $\alpha \leq 5 \%$ if there was significant. The results showed that the addition of SPI $30 \%$ and Na-alginate up to $0.2 \%$ increased the protein content of instant noodles to $31.36 \pm 0.39 \%-34.44 \pm$ $0.34 \%$, water absorption for 5 minutes of cooking was $147 \%$, cooking time $6.16 \pm 0.22$ minutes. Overall, the instant noodle is in the category of rather like to like the taste, aroma, color and texture. Composite flour (corn flour and tapioca) can substitute 50\% of wheat flour to produce the instant noodles. The protein contain is $34.44 \%$, with a contribution of $30 \%$ SPI and Na-alginate $0.2 \%$.
\end{abstract}

Keywords: Na-alginate, instant noodles, soy protein isolate

\begin{abstract}
ABSTRAK
Pemanfaatan protein nabati telah banyak dikembangkan pada produk mie protein tinggi. Indonesia termasuk Negara yang mengkonsumsi mie urutan kedua di dunia setelah Cina. Kondisi tersebut menyebabkan impor gandum terus meningkat. Upaya untuk menghasilkan mie protein tinggi dan mengurangi kebutuhan gandum, maka diperlukan alternatif bahan baku lokal guna menggantikannya. Tujuan penelitian adalah untuk memanfaatkan tapioka dan tepung jagung sebagai bahan substitusi tepung gandum dalam pembuatan mie instan, yang mana isolat protein kedelai (SPI) dan Na-alginat digunakan untuk produksi mie instan protein tinggi. Rancangan acak kelompok pola faktorial digunakan dalam penelitian. Faktor I adalah SPI dan faktor II Na-alginat yang diulang 3 kali. Variasi hasil pengamatan dianalisis variannya dan dilanjutkan dengan uji tukeys $\alpha \leq 5 \%$, jika ada perbedaan. Hasil penelitian menunjukkan bahwa penambahan
\end{abstract}


SPI $30 \%$ dan Na-alginat sampai $0,2 \%$ pada mie instan mengandung protein $31,36 \pm 0,39$ $\%-34,44 \pm 0,34 \%$, daya serap air selama 5 menit pemasakan adalah $147 \%$, waktu masak $6,16 \pm 0,22$ menit. Secara keseluruhan mie instan masuk kategori cukup suka sampai suka terhadap rasa, aroma, warna dan tekstur. Tepung komposit (tepung jagung dan tapioka) bisa menggantikan $50 \%$ tepung gandum untuk membuat mie instan yang ditambah $30 \%$ SPI dan alginat $0,2 \%$, dan mie tersebut mengandung protein $34,44 \%$.

Kata kunci: mie instan, Na-alginat, SPI.

\section{PENDAHULUAN}

Konsumsi mie instan di Indonesia diperkirakan mencapai 14,8 miliar bungkus tiap tahun. Angka ini meningkat dari konsumsi tahun sebelumnya, yakni 13,2 miliar bungkus, Diproyeksikan konsumsi tersebut akan terus meningkat dari tahun ke tahun seperti yang dilaporkan World Instant Noodles Association (Chairani, 2015). Berdasarkan ranking konsumsi mie di Indonesia berada pada urutan kedua di dunia setelah China. Kondisi tersebut berpengaruh terhadap jumlah impor gandum di Indonesia, karena sampai saat ini gandum adalah bahan baku utama untuk pembuatan mie.

Konsumsi protein dari daging merah dan produk-produknya telah banyak dikaitkan dengan kanker dalam pertemuan International Agency for Research on Cancer, diduga daging merah dan daging olahan juga sebagai karsinogenik (Bouvard et al. 2015). Beberapa studi epidemiologi baru dan ulasan baru mendukung keputusan IARC tersebut (Domingo dan Nadal, 2017). Oleh karena itu isolat protein kedelai (SPI) adalah salah satu pilihan sebagai sumber protein. Fokus dari penelitian ini adalah penambahan SPI dan Na-alginat untuk pembuatan mie instan berprotein tinggi dari tepung terigu yang disubtitusi tepung komposit tepung singkong dan tepung jagung.

Faktor yang membuat sifat elastis dan kenyal pada mie adalah protein gluten dari tepung gandum/terigu. Pada umumnya mie instan dibuat dari bahan utama tepung terigu dan ditambah bahan tambahan lain untuk meningkatkan tekstur, struktur dan rasa dari produk akhir (Choy, Hughes dan Small, 2010; Sa'adah et al., 2015). Tepung terigu yang memiliki kadar protein yang tinggi biasanya mengandung gluten yang tinggi sehingga dapat memberikan elastisitas dari produk mie (Rosmeri, Vinsensia dan Bella, 2013).

Mie instan dibagi dalam dua golongan yaitu mie instan kering mengandung kadar air $8-12 \%$ dan mie instan goreng mengandung kadar air 2-5\%. Mie instan kering mempunyai kelebiahan di antaranya mengandung lemak lebih rendah yaitu 3\% dibandingkan dengan mie goreng yang mengandung minyak 15-20\%. Mie instan kering juga memiliki masa simpan yang lebih lama sehingga dapat mengurangi risiko penyakit jantung (Gulia, Dhaka dan Khatkar, 2014).

Tepung komposit (tepung jagung dan tepung singkong) tidak mengandung protein gluten, sehingga menjadi kendala dalam membentuk karakter elastis dan kenyal. Oleh karena itu dalam penelitian ini memanfaatkan soy protein isolat (SPT) atau isolat protein kedelai yang dikombinasikan dengan $\mathrm{Na}$ alginat untuk memperbaiki sifat elastis dan kekenyalan pada mie instan yang sebagian bahan bakunya diganti tepung komposit.

Kedelai mengandung sekitar $40 \%$ protein dan $20 \%$ minyak, setelah minyak dipisahkan pada suhu yang lebih rendah, isolat protein kedelai (SPI) dapat diisolasi. SPI telah banyak digunakan dalam industri makanan (Nishinari et al., 2016). Koagulan yang paling umum digunakan untuk membuat tahu adalah glucono-deltalactone (GDL) dan kalsium sulfat (CaSO4). Kohyama, Sano, dan Doi (1995 dalam Nishinari et al., 2016) telah mempelajari gelasi SPI menggunakan koagulan ini, dan menemukan bahwa gelasi oleh kalsium lebih cepat daripada oleh GDL dan kekuatan molekul utama adalah interaksi hidrofobik.

Alginat adalah polisakarida anionik 
alami yang diekstrak dari dinding sel rumput laut (Szekalska et al., 2016). Sinurat dan Marliani (2017) melaporkan bahwa hasil analisis fisik dan kimia dari alginat yang disaring dengan penyaring filter press memiliki nilai rata-rata rendemen $10,91 \pm 4,33 \%$, viskositas $82,66 \pm 112,46 \mathrm{cP}$, derajat putih $60,53 \pm 9,09 \%$, dan kekuatan gelnya mencapai $353,54 \pm 184,51 \mathrm{~g} / \mathrm{cm} 2$. Wardani dan Manuhara (2009) melaporkan bahwa penambahan Na-alginat $0,75 \%$ pada bakso dari bahan baku ikan tenggiri mampu meningkatkan kekenyalan. Pemanfaatan alginat dalam industri makanan karena: (1) mampu membentuk larutan yang viscous, (2) bersifat stabil pada temperature dan $\mathrm{pH}$ tinggi, (3) dapat membentuk gel dengan bantuan ion $\mathrm{Ca}^{++}$dan mampu membentuk gel yang bersifat thermostable (Rasyid, 2003). Pada proses pembuatan mie alginat berfungsi sebagai bahan pengenyal atau pengental, yaitu membuat tekstur adonan agar menjadi kenyal dan tidak mudah hancur (Sukamto et al., 2019).

Penelitian bertujuan untuk mengetahui pengaruh interaksi antara SPI dengan $\mathrm{Na}$ alginat dalam pembuatan mie instan, yang mana sebagian dari tepung terigu digantikan oleh tepung komposit (tepung singkong dan tepung jagung). Implikasi dari hasil penelitian ini adalah untuk mengurangi ketergantungan terhadap tepung gandum yang sampai saat ini masih impor.

\section{METODE}

Bahan-bahan yang digunakan: Tepung jagung hibrida varietas BISI dari petani local di Kabupaten Kediri, Soy protein isolate (SPI) atau isolat protein kedelai produksi Shandong Protein Co. Ltd. Shandong Province China, tepung tapioka merek pak tani gunung produksi PT. BUDI STARCH \& SWEETENER TBK Lampung Indonesia. Tepung terigu merek cakra kembar produksi PT Bogasari Indonesia, dan Na-alginate kategori food grade.

Alat yang digunakan dalam pembuatan mie terdiri dari mesin pencampur tepung dan pencetak mie skala laboratorium produksi
PT. Maxindo. Penelitian menggunakan rancangan acak kelompok (RAK) pola factorial (dua factor) yaitu penambahan SPI (isolat protein kedelai) yang terdiri dari tiga level $(20 \%, 25 \%, 30 \%)$, dan penambahan $\mathrm{Na}$-alginat yang terdiri dari dua level $(0,1 \%$, $0,2 \%$ ). Seluruh perlakuan diulang 3 kali. Analisa varian (anova) terhadap variable penelitian menggunakan aplikasi softwere SPSS apabila terdapat perbedaan maka dilakukan dengan analisis tukey $\alpha \leq 5 \%$.

\section{Pelaksanaan penelitian}

Formulasi bahan baku terdiri dari terigu, tapioka dan tepung jagung dengan rasio 50: 25: 25. Ketiga bahan tersebut diaduk sampai homogen menggunakan mesin pencampur adonan. Isolat protein kedelai ditambahkan dalam adonan sesuai perlakuan dan diaduk lagi sampai rata. Adonan ditambah air $30 \%$, garam $1,5 \%$, air ki kusus untuk mie $0,2 \%$ dan ditambahkan Na-alginat sesuai perlakuan. Bahan diaduk sampai homogen dan kalis.

Adonan yang sudah kalis didiamkan selama \pm 15 menit. Seluruh adonan pada masing-masing perlakukan dipipihkan menggunakan mesin pencetak mie ukuran tebal $2 \mathrm{~mm}$ lebar $3 \mathrm{~mm}$ dan panjang $15 \mathrm{~cm}$. Calon mie instan hasil cetakan didiamkan selama 3 menit, selanjutnya dikukus selama 15 menit suhu $100^{\circ} \mathrm{C}$. Mie hasil pengukusan dikeringkan pada suhu $70^{\circ} \mathrm{C}$ sampai kadar air 10\%-12\%. Mie instan dikemas dalam plastik PE dan siap untuk dilakukan evaluasi. Pengamatan terhadap mie instan meliputi:

\section{Komposisi proksimat}

Meliputi: kadar air, kadar protein, kadar lemak dan kadar serat menggunakan metode AOAC (2005).

\section{Sifat fisik}

Meliputi: densitas kamba dievaluasi mengacu pada metode (Kumalasaria, Setyoningrum, dan Ekafitri, 2015) yang dimodifikasi sebagai berikut: gelas ukur diisi biji sawi hingga $10 \mathrm{ml}$, selanjutnya sampel yang telah diketahui beratnya dimasukkan dalam gelas ukur tersebut dan diketuk-ketuk sampai tidak terdapat rongga-rongga terisi seluruhnya. Kenaikan 
volume biji sawi dalam gelas ukur dihitung. Densitas kamba $(\mathrm{g} / \mathrm{ml})$ dapat dihitung dari hasil pembagian berat sampel (g) dengan kenaikan volume biji sawi (ml). Pengukuran dilakukan 2 kali setiap sampel.

\section{Cooking time (waktu masak)}

Mie instan dimasak dalam air mendidih dalam beaker glass $1000 \mathrm{ml}$ dengan perbandingan air dan mie 1:1. Kemudian mie instan dimasukkan dan dimasak hingga matang. Waktu pemasakan dihitung sejak mie instan dimasukkan ke dalam beaker glass yang berisi air mendidih hingga masak (Noviasari et al., 2013). Tanda mie sudah masak adalah tidak ada noktah pada bagian dalam mie yang belum tergelatinisasi sempurna.

\section{Daya serap air}

Kemampuan mengabsorbsi (daya serap) air selama pemasakan dievaluasi dengan menggunakan metode Billina, Waluyo dan Suhandy (2014) yang dimodifikasi sebagai berikut: Mie instan sebelum ditimbang terlebih dahulu sebelum dimasak (Wa), selanjutnya dimasak sampai matang dan ditimbang mie yang sudah masak $(\mathrm{Wb}$ ). Kemampuan mengabsorbsi (daya serap) air dapat dihitung menggunakan persamaan sebagai berikut:

Dimana:

$$
\operatorname{DSA}(\%)=\frac{(W B-W A)}{W A} \times 100 \%
$$

$\mathrm{WA}=$ Berat mie kering sebelum dimasak $(\mathrm{g})$

$\mathrm{WB}=$ Berat mie setelah dimasak $(\mathrm{g})$

Kemampuan mengabsorbsi (daya serap) air selama perendaman diamati dengan cara sebagai berikut: Mie instan sebelumnya ditimbang terlebih dahulu (Ma), selanjutnya direndam dalam air sampai berat konstan dan ditimbang $(\mathrm{Mb})$. Kemampuan mengabsorbsi (daya serap) air dapat dihitung menggunakan persamaan sebagai berikut:

Dimana:

$$
\operatorname{DSA}(\%)=\frac{(M a-M b)}{M a} \times 100 \%
$$

$\mathrm{Ma}=$ Berat mie kering sebelum direndam $(\mathrm{g})$

$\mathrm{Ma}=$ Berat mie setelah direndam $(\mathrm{g})$

\section{Sifat sensoris}

Sifat sensoris ditentukan berdasar uji organoleptik skala hedonik menggunakan 10 orang panelis. Parameter yang diuji untuk mie kering adalah rasa, aroma, warna, dan tekstur. Skala hedonik yang digunakan adalah skala numerik antara 1-6 (1= sangat tidak suka, $2=$ tidak suka, $3=$ cukup suka, $4=$ suka, $5=$ sangat suka, dan $6=$ sangat suka sekali).

\section{HASIL DAN PEMBAHASAN}

\section{Komposisi proksimat}

\section{Protein}

Data kadar protein mie instan (Tabel 1) menunjukkan adanya perbedaan yang nyata, dimana semakin banyak SPI (isolat protein kedelai) yang ditambahkan dalam adonan, kadar protein mie instan juga semakin besar. Pengaruh interaksi antara perlakuan penambahan SPI dengan Na-alginat tidak berbeda nyata $(\mathrm{P}=0,05)$. Kadar protein terendah diperoleh pada perlakuan penambahan SPI sebesar $20 \%$ dan Na-alginat $0,1 \%$. Sedangkan kadar protein tertinggi $(34,44 \%)$ terdapat pada perlakuan penambahan SPI 30\% dan Na- alginat 0,2\%. Kadar protein tersebut lebih tinggi dari mie instan yang ditambah tepung tahu yaitu $18 \%$ (Marsono dan Astanu, 2002). Perbedaan kadar protein pada mie instan tersebut sejalan dengan jumlah SPI yang ditambahkan dalam adonan. Isolat protein kedelai mengandung protein $90 \% \pm 2 \%$. Kondisi tersebut menyebabkan kenaikan kadar protein dalam mie instant jika yang ditambahkan semakin banyak. Berdasarkan hasil analisis kimia tentang SPI dari Qingdao crown IMP \& Exp. Corp Ltd. bahwa protein dalam SPI adalah $90,12 \%$.

Tabel 1. Komposisi protein proksimat mie instan hasil perlakuan penambahan SPI dan Na-alginat.

\begin{tabular}{lll}
\hline No & $\begin{array}{l}\text { Perlakuan SPI \& } \\
\text { Na-alginat }\end{array}$ & $\begin{array}{l}\text { Kadar Protein } \\
(\%)\end{array}$ \\
\hline 1 & $20 \% ; 0,1 \%$ & $24,79 \pm 0,77 \mathrm{a}$ \\
2 & $20 \% ; 0,2 \%$ & $24,81 \pm 0,37 \mathrm{a}$ \\
3 & $25 \% ; 0,1 \%$ & $29,55 \pm 0,77 \mathrm{bc}$ \\
4 & $25 \% ; 0,2 \%$ & $29,61 \pm 0,83 \mathrm{c}$ \\
5 & $30 \% ; 0,1 \%$ & $31,36 \pm 0,39 \mathrm{~d}$ \\
6 & $30 \% ; 0,2 \%$ & $34,44 \pm 0,34 \mathrm{e}$ \\
\hline
\end{tabular}

Keterangan: angka yang didampingi huruf berbeda berarti berbeda nyata $(\mathrm{P}=0.05)$ 


\section{Kadar air}

Kadar air mie instan hasil penelitian pada seluruh perlakuan adalah 7,05\% 9,33\%. Hasil analisis ragam pengaruh interaksi antara SPI dengan Na-alginat tidak berbeda nyata $(\mathrm{P}=0.05)$, diduga karena air yang terkandung dalam mie instan sebagian besar adalah air bebas yang terikat secara fisik, sehingga pada pemanasan pada suhu $70^{\circ} \mathrm{C}$ air yang terikat secara fisik dalam adonan tersebut mudah menguap. Andarwulan et al. (2011) menyatakan bahwa selama proses pengeringan air bebas yang terikat secara fisik mudah untuk diuapkan.

\section{Kadar serat kasar dan lemak kasar}

Kadar serat kasar dan lemak pada mie instan dari seluruh perlakuan dalam penelitian masing-masing berkisar 3,67\% $4,33 \%$ dan $2,81 \%$ - 3,67\%. Hasil analisa ragam pengaruh interaksi antara SPI dengan Na-alginat tidak berbeda nyata $(\mathrm{p}=0.05)$ terhadap kadar serat. Hal ini disebabkan karena kadar serat SPI sangat rendah, sehingga peningkatan penambahan SPI tidak berpengaruh nyata. Kadar lemak dari mie instan juga tidak berbeda nyata dan rendah, hal ini disebabkan karena SPI diisolasi dari tepung kedelai yang bebas lemak sehingga peningkatan penambahan SPI juga tidak berpengaruh terhadap jumlah lemak dalam mie instan. Kadar lemak SPI hasil analisa Qingdao crown IMP \& Exp. Corp Ltd. adalah $0,44 \%$. Kadar lemak dan serat kasar seluruh perlakuan lebih rendah dibandingkan dengan mie instan barbagai merek yang dilaporkan oleh Ete, Suciptawati dan Nilakusmawati (2014).

\section{Sifat fisik \\ Densitas kamba}

Densitas kamba mie instan dari seluruh perlakuan penambahan SPI (isolat protein kedelai) dan Na-alginat adalah $1,53 \mathrm{~g} / \mathrm{ml}$ $1,62 \mathrm{~g} / \mathrm{ml}$. Hasil analisa ragam menunjukkan bahwa interaksi antara perlakuan SPI dengan Na-alginat tidak berbeda nyata $(\mathrm{P} \leq 0,05)$. Demikian juga pengaruh dari masing-masing faktor baik SPI maupun Na-alginat juga tidak berpengaruh nyata. Hal ini diduga bahwa kerapatan adonan setelah gelatinisasi dan pengeringan relatif seragam, sehingga pada satuan berat yang sama menghasilkan volume yang hampir sama. Amir dan Adi (2016) menyatakan bahwa dalam pengembangan produk pangan SPI berperan sebagai agent pengikat adonan, emulsifier, serta gelling agent, serta memperbaiki tekstur.

\section{Waktu masak}

Waktu masak mie instan dengan menggunakan parameter penyerapan air setiap menit yang diberi perlakuan penambahan isolat protein kedelai dan alginat masak pada menit pertama berkisar $45,67 \%-67,33 \%$, pada menit kedua berkisar $59,67 \%$ - 96,67\%, pada menit ketiga berkisar $67,00 \%$ - 106,67\%, pada menit keempat berkisar $72,00 \%-117,33 \%$, dan pada menit kelima bekisar 79,67\% - 147,00\%.

Tabel 2. Waktu masak mie instan dari pengaruh proporsi SPI dan Naalginat

\begin{tabular}{cc}
\hline SPI \& Na-Alginat & Rata - Rata (menit) \\
\hline $20 \% ; 0,1 \%$ & $4,67 \pm 0,67$ \\
$20 \% ; 0,2 \%$ & $4,33 \pm 0,44$ \\
$25 \% ; 0,1 \%$ & $5,00 \pm 0,44$ \\
$25 \% ; 0,2 \%$ & $5,33 \pm 0,44$ \\
$30 \% ; 0,2 \%$ & $5,67 \pm 0,44$ \\
$30 \% ; 0,1 \%$ & $6,16 \pm 0,22$ \\
\hline
\end{tabular}

Data yang terdapat pada Tabel 2 . Menunjukkan bahwa waktu masak mie instan yang ditambah isolat protein lebih banyak waktu pemasakan mengalami peningkatan. Pada perlakuan penambahan isolat protein kedelai 30\% waktu masak tertinggi. Waktu masak dipengaruhi oleh komposisi bahan yang digunakan. Labropoulos dan Varzakas (2016) melaporkan bahwa pada suhu $68^{\circ} \mathrm{C}$ sudah terjadi gel pada SPI (isolat protein kedelai).

\section{Daya serap air selama perendaman}

Kecepatan penyerapan air selama perendaman mie instan sepeti pada Gambar 1. Rata-rata mie instan yang menggunakan SPI $30 \%$ kecepatan penyerapan air lebih rendah dibandingkan dengan yang menggunakan SPI $25 \%$ dan $20 \%$. Protein dapat bersifat menghalangi penyerapan air di dalam granula pati (Widatmoko dan Estiasih, 2015). Penggunaan SPI dalam penelitian 
mencapai $30 \%$, kondisi tersebut menyebabkan air yang masuk dalam granula pati menjadi lebih sulit, karena protein yang semakin tinggi dalam adonan mie menyebabkan air yang masuk dalam adonan semakin lambat. Demikian juga penggunaan Na-alginat 0,2\% kecepatan penyerapan air lebih rendah dibandingkan dengan yang 0,1 $\%$. Tanpa perebusan absorbsi air dalam adonan terhambat oleh adanya hidrokoloid (Na-alginate). Billina, Waluyo dan Suhandy (2014) melaporkan bahwa semakin banyak bubur rumput laut yang digunakan dalam adonan mie semakin rendah nilai daya serap air. Setelah perendaman berjalan 5 menit dievaluasi daya serap air dari seluruh perlakuan. Berdasarkan hasil analisa ragam menunjukkan bahwa pengaruh interaksi antara perlakuan SPI dengan $\mathrm{Na}$-an alginat tidak berbeda nyata. Sedangkan pengaruh penambahan protein berpengaruh tidak berbeda nyata, dan untuk penambahan alginat tidak berbeda nyata terhadap daya serap air selama perendaman.

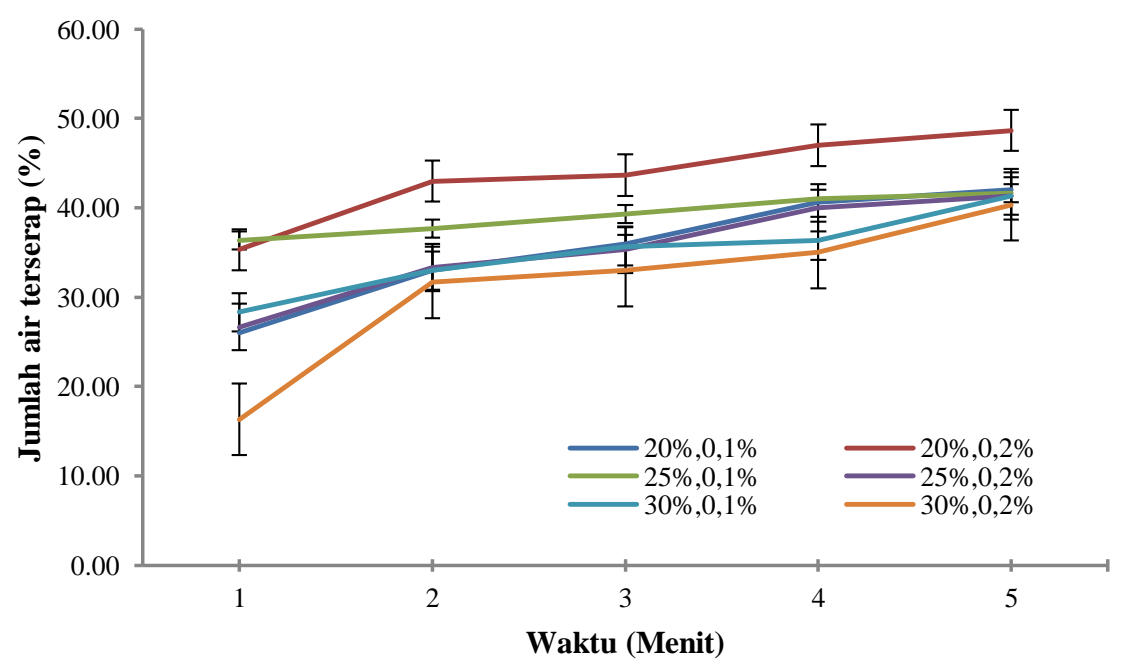

Gambar 1. Pengaruh penggunaan SPI dan Na-alginat terhadap daya serap air selama perendaman mie.

\section{Daya serap air selama pemasakan}

Kecepatan penyerapan air selama pemasakan (Gambar 2) sangat berbeda dengan kecepatan penyerapan air saat perendaman dalam air dingin (Gambar 1).

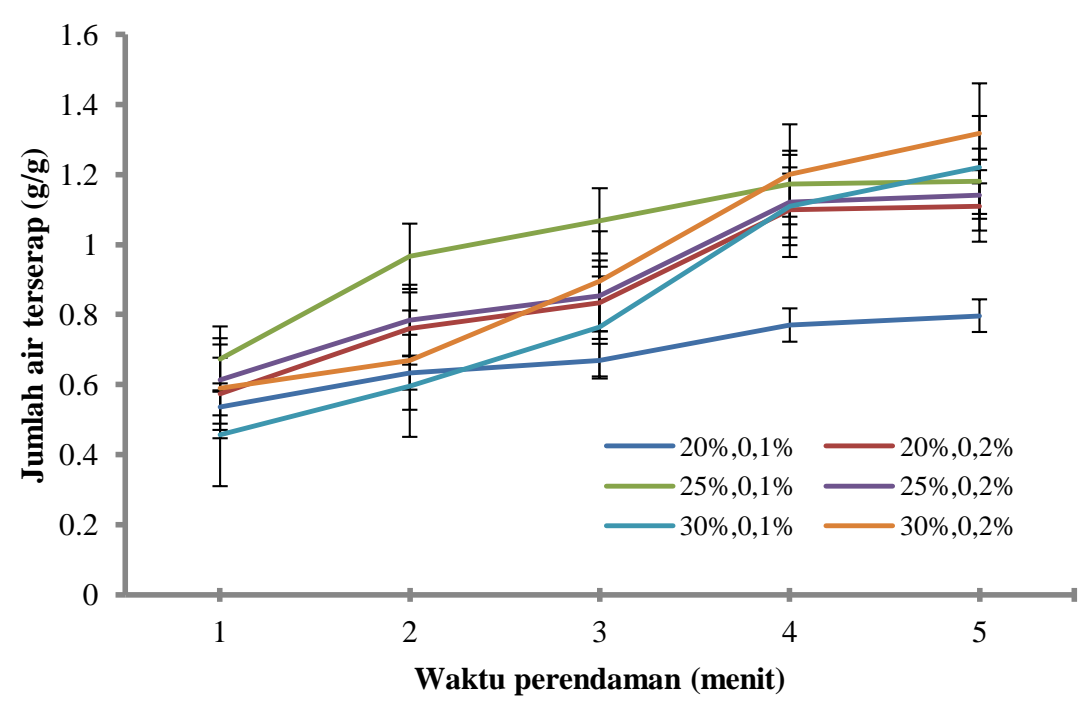

Gambar 2. Pengaruh penggunaan SPI dan Na- Alginat terhadap daya serap air selama pemasakan mie instan. 
Perlakuan penambahan isolat protein kedelai dan Na-alginat selama pemasakan pada menit pertama berkisar 45,67\% $67,33 \%$, pada menit kedua berkisar 59,67\% $96,67 \%$, pada menit ketiga berkisar $67,00 \%$ $106,67 \%$, pada menit keempat berkisar $72,00 \%$ - 117,33\%, dan pada menit kelima bekisar 79,67\% - 147,00\%. Data penelitian menunjukkan bahwa daya serap air selama pemasakan mie instan yang ditambah dengan SPI $30 \%$ dan Na-alginat $0,2 \%$ kecepatan penyerapan air dan jumlah air yang diserap lebih tinggi setelah menit ke 4. Hal ini berbanding terbalik dengan saat perendaman dalam air dingin. Secara umum semakin tinggi SPI dan Na-alginat yang ditambahkan semakin besar air yang terserap dalam mie instan. Setelah pemasakan 5 menit daya serap air dievaluasi, dan hasil analisa ragam menunjukkan bahwa interaksi antara SPI dan Na-alginat berbeda sangat nyata.

Daya serap air pada menit ke-5 perubahan jumlah air yang terserap relatif besar untuk seluruh perlakuan. Na- alginat dapat mengabsorpsi air dan bisa digunakan dalam produk mie instan yang ditambah isolat protein kacang hijau (Sukamto et al., 2019). Menurut Nugrahani (2005) pada penambahan jumlah air yang sama tepung yang mengandung protein tinggi mempunyai daya serap air lebih besar daripada tepung dengan kandungan protein rendah. Sehingga semakin besar konsentrasi SPI dan $\mathrm{Na}$ alginat yang ditambahkan meningkatkan kemampuan mengapsorsi air oleh mie instan selama pemasakan.

\section{Sifat sensoris}

Penilaian organoleptik produk mie instan berdasarkan pengamatan dengan panca indra manusia meliputi rasa, aroma, warna dan tekstur (Tabel 3). Pengujian dilakukan menggunakan skala hedonik oleh 10 orang panelis. Berdasarkan hasil analisis data menunjukkan bahwa perlakuan penambahan SPI $(20 \%, 25 \%, 30 \%)$ dan Na-alginat $(0,1 \%$ dan $0,2 \%$ ) tidak berpengaruh nyata terhadap rasa, aroma, warna dan tekstur mie instan matang yang dihasilkan.

Tabel 3. Nilai organoleptik rasa, aroma, warna dan tekstur dari perlakuan penambahan SPI dan Na-alginat

\begin{tabular}{ccccc}
\hline \multirow{2}{*}{ SPI \& Na-alginat } & \multicolumn{4}{c}{ Nilai organoleptik } \\
\cline { 2 - 5 } & Rasa & Aroma & Warna & Tekstur \\
\hline $20 \% ; 0,1 \%$ & $4,2 \pm 0,79$ & $3,9 \pm 0,72$ & $4,0 \pm 0,60$ & $3,9 \pm 0.72$ \\
$20 \% ; 0,2 \%$ & $4,4 \pm 0,68$ & $3,8 \pm 0,64$ & $4,0 \pm 0,72$ & $3,9 \pm 0,72$ \\
$25 \% ; 0,1 \%$ & $3,8 \pm 0,64$ & $4,0 \pm 0,80$ & $4,0 \pm 0,40$ & $4,0 \pm 0,80$ \\
$25 \% ; 0,2 \%$ & $3,7 \pm 0,76$ & $4,0 \pm 0,40$ & $4,0 \pm 0,60$ & $4,2 \pm 0,80$ \\
$30 \% ; 0,2 \%$ & $3,6 \pm 0,92$ & $3,8 \pm 0,64$ & $3,8 \pm 0,80$ & $4,0 \pm 0,80$ \\
$30 \% ; 0,1 \%$ & $3,4 \pm 0,88$ & $3,6 \pm 0,60$ & $3,7 \pm 0,70$ & $4,0 \pm 0,40$
\end{tabular}

Rasa merupakan faktor yang sangat penting dalam menentukan keputusan akhir konsumen untuk menerima atau menolak suatu produk pangan. Data pada Tabel 3 menunjukkan bahwa semakin tinggi penambahan SPI nilai kesukaan terhadap rasa cenderung terjadi penurunan, hal ini karena rasa SPI lebih mendominasi dalam produk mie instan tersebut.

Aroma merupakan penilaian terhadap produk mie instan dengan menggunakan indra penciuman. Perlakuan penambahan SPI $25 \%$ yang dikombinasikan dengan penggunaan Na-alginate 0,1 dan $0,2 \%$ cenderung memiliki tingkat kesukaan aroma yang lebih tinggi. Sedangkan pada penggunaan SPI sampai $30 \%$ nilai kesukaan terhadap aroma cenderung terjadi penurunan, hal ini karena rasa SPI memiliki aroma khas kedelai.

Warna mie instan menunjukkan bahwa semakin tinggi penambahan SPI nilai kesukaan terhadap warna cenderung terjadi penurunan, hal ini karena SPI memiliki warna yang tidak seputih tepung yang lain (gandum, tapioka dan jagung). Di samping 
itu semakin tinggi SPI kemungkinan terjadinya reaksi millard juga semakin besar sehingga berdampak terhadap terjadinya warna kecokelatan mie instan.

Tekstur mie instan matang cenderung semakin tinggi penggunaan SPI nilai kesukaan terhadap tekstur semakin meningkat (Tabel 3). Hal ini diduga berhubungan dengan kemampuan dalam menyerap dalam menahan air dari mie instan (Gambar 2) yang relatif tinggi sehingga memberikan tekstur yang lebih empuk.

\section{KESIMPULAN}

Penambahan isolat protein kedelai (SPI) dan Na-alginat pada tepung komposit (jagung dan singkong) yang disubstitusikan pada tepung gandum $50 \%$ dalam pembuatan mie instan berpengaruh sangat nyata terhadap kandungan kadar protein dan daya serap air selama pemsakan. Waktu masak antara 4,33 sampai 6,16 menit dan densitas kamba $1,53 \mathrm{~g} / \mathrm{ml}-1,62 \mathrm{~g} / \mathrm{ml}$. Kadar protein tertinggi diperoleh pada perlakuan penambahan SPI $30 \%$ yang membutuhkan waktu pemasakan 5,67 - 6,16 menit, daya serap air selama pemasakan menit ke 5 mencapai $147 \%$. Nilai rasa, aroma warna dan tekstur agak suka sampai suka. Nilai rasa $=3,55$, aroma $=3,7$, warna $=3,75$ dan tekstur $=4,05$.

Tepung komposit campuran tepung terigu, tapioca dan tepung jagung dengan rasio 50: 25: 25 dapat ditambah SPI sampai $30 \%$ dan alginate $0,1 \%$ sampai $0,2 \%$ untuk menghasilkan mie instan yang mengandung protein tinggi $(31,36$ - 34,44 g/100bk) dan produk masih diterima oleh panelis.

Mie instan masih memiliki rasa, aroma, dan tekstur yang masih belum sesuai dengan standar mie instan pada umumnya karena aroma jagung, singkong dan SPI masih mendominasi. Oleh karena itu masih disarankan penelitian lanjutan penambahan bumbu untuk memperbaikinya.

\section{UCAPAN TERIMA KASIH}

Ucapan ini disampaikan kepada DRPM Kemristek DIKTI atas bantuan dana penelitian dan LPPM Universitas Widyagama Malang atas batuan dana penulisan artikel ilmiah.

\section{DAFTAR PUSTAKA}

Alfian, B. \& Susanti, R. (2012). Analisis senyawa fenolik, 43-65, Semarang: Universitas Diponegoro Press.

Amir, R. A., \& Adi, A. C. (2017). Pengaruh substitusi tempe dan penambahan isolatd soy protein terhadap mutu organoleptik dan kandungan protein sosis ayam. Media Gizi Indonesia, 12(1), 80-87. https://dx.doi.org/10.5465/AMR.2001. 4011928

Andarwulan, N. Kusnandar, F. \& Herawati, D. (2011). Analisis pangan. Jakarta: Dian Rakyat.

AOAC. (2005). Official methods of analysis. Washington: Association of Official Analytical Chemists.

Billina, A., Waluyo, S., \& Suhandy, D. (2014). Kajian sifat fisik mie basah dengan penambahan rumput laut. Jurnal Teknik Pertanian Lampung, 4(2), 109-116.

Bouvard, V., Loomis, D., Guyton, K. Z., Grosse, Y., Ghissassi, F. E., Benbrahim-Tallaa, L., ... \& Straif, K. International Agency for Research on Cancer Monograph Working Group 2015. Carcinogenicity of consumption of red and processed meat. Lancet. Oncol, 16, 1599-1600. https://doi .org/10.1016/S1470-2045(15)00444-1

Chairani F. (2015). Konsumsi mie instan masyarakat Indonesia. Kompasiana. https://www.kompasiana.com.

[Diakses 3 juli 2018].

Choy, A. L., Hughes, J. G., \& Small, D. M. (2010). The effects of microbial transglutaminase, sodium stearoyl lactylate and water on the quality of instant fried noodles. Food Chemistry, 122(4), 957-964. https://doi.org/10.1016/j.foodchem.200 9.10.009

Domingo, J. L., \& Nadal, M. (2017). 
Carcinogenicity of consumption of red meat and processed meat: a review of scientific news since the IARC decision. Food and chemical toxicology, 105, 256-26. https://doi.org/10.1016/j.fct.2017.04.02 8

Ete, A. A., Suciptawati, N. L. P., \& Nilakusmawati, D. P. E., (2014). Pengelompokan berbagai merk mi instan berdasarkan kemiripan kandungan gizi dengan menggunakan analisis biplot. E-Jurnal Matematika, 3(2), 53-63.

Gulia, N., Dhaka, V., \& Khatkar, B. S. (2014). Instant noodles: processing, quality, and nutritional aspects. Critical reviews in food science and nutrition, 54(10), 1386-1399. https://doi.org/10.1080/10408398.2011 .638227

Kumalasari, R., Setyoningrum, F., \& Ekafitri, R. E. (2015). Karakteristik fisik dan sifat fungsional beras jagung instan akibat penambahan jenis serat dan lama pembekuan. Jurnal Pangan, 24(1), 37-48. http://dx.doi.org/10.33964/jp.v24i1.41

Labropoulos, A. E., \& Varzakas, T. H. (2016). Rheological studies of physical soy protein gels. Current Research in Nutrition and Food Science Journal, 4(Special Issue Nutrition in Conference October 2016), 18-25. http://dx.doi.org/10.12944/CRNFSJ.4.S pecial-Issue-October.03

Marsono, Y., \& Astana, P. W. (2002). Pengkayaan protein mie instant dengan tepung tahu. Agritech, 22(3), 99103. https://doi.org/10.22146/agritech.1 3541

Nishinari, K., Fang, Y., Guo, S., \& Phillips, G. O. (2014). Soy proteins: A review on composition, aggregation and emulsification. Food hydrocolloids, 39, 301-318.

https://doi.org/10.1016/j.foodhyd.2014. 01.013

Noviasari, S., Kusnandar, F., \& Budijanto, S. (2013). Pengembangan beras analog dengan memanfaatkan jagung putih. Jurnal Teknologi dan Industri Pangan, 24(2),

194-200. https://doi.org/10.6066/jtip.2013.24.2.1 94

Nugrahani, D. M. (2005). Perubahan karakteristik dan kualitas protein pada mie basah matang yang mengandung formaldehid dan boraks [Tugas Akhir]. Institut Pertanian Bogor.

Rasyid, A. (2003). Algae cokelat (phaeophyta) sebagai sumber alginat. Jakarta: Pusat Penelitian Oseanografi-LIPI.

Rosmeri, V. I., Monica, B. N., \& Budiyati, C. S. (2013). Pemanfaatan tepung umbi gadung (dioscorea hispida dennst) dan tepung mocaf (modified cassava flour) sebagai bahansubstitusidalam pembuatan mie basah, mie kering, dan mie instan. Jurnal Teknologi Kimia dan Industri, 2(2), 246-256.

Sa'adah, E. T., Husna, N., Anggono, W. A., Suciani, E. I., \& Wahyuni, R. (2015). Karakteristik mie kering tersubstitusi tepung bungkil kacang tanah dengan penambahan getah pepaya kering (Carica Papaya L.) terhadap kualitas fisikokimia dan organoleptik. Teknologi Pangan : Media Informasi dan Komunikasi Ilmiah Teknologi Pertanian, 6(2). https://doi.org/10.35891/tp.v6i2.468

Sinurat, E., \& Marliani, R. (2017). Karakteristik Na-Alginat dari rumput laut cokelat Sargassum crassifolium dengan perbedaan alat penyaring. Jurnal Pengolahan Hasil Perikanan Indonesia, 20(2), 351-361. http://dx.doi.org/10.17844/jphpi.v20i2. 18103

Sukamto, S., Azizah, R., Suprihana, S., \& Karim, F. (2019). Production of high protein noodles using wheat flour fortified with composite flour and mungbean protein. In: Herlinda $\mathrm{S}$ et al. (Edt.), Prosiding Seminar Nasional Lahan Suboptimal 2019, Palembang 45 September 2019. pp. 487-495. Palembang: Unsri Press. 
Szekalska, M., Puciłowska, A., Szymańska, E., Ciosek, P., \& Winnicka, K. (2016). Alginate: current use and future perspectives in pharmaceutical and biomedical applications. International Journal of Polymer Science, 2016(1). https://doi.org/10.1155/2016/7697031

Wardani, D.W. Kawiji, \& Manuhara. G.J., (2009). Isolasi dan karakterisasi natrium alginat dari rumput laut Sargassum sp. untuk pembuatan bakso ikan tenggiri (Scomberomorus commerson. Biofarmasi, 7(2), 59-67. https://doi.org/10.13057/biofar/f07020 1

Widatmoko, R. B., \& Estiasih, T. (2015). Karakteristik fisikokimia dan organoleptik mie kering berbasis tepung ubi jalar ungu pada berbagai tingkat penambahan gluten. Jurnal Pangan dan Agroindustri, 3(4), 13861392. 